\title{
CITRA PEREMPUAN DAN GAYA BAHASA DALAM KUMPULAN PUISI IBU MENDULANG ANAK BERLARI SEBAGAI MATERI PEMBELAJARAN SASTRA
}

\author{
Yuvensia Kharisma Novena, Raheni Suhita, Edy Suryanto \\ Universitas Sebelas Maret \\ Surel: yuvensia@student.uns.ac.id
}

\begin{abstract}
Abstrak: Penelitian ini bertujuan untuk mendeskripsikan dan menjelaskan: (1) Citra Perempuan dalam kumpulan Puisi Ibu Mendulang Anak Berlari; (2) Gaya Bahasa dalam kumpulan Puisi Ibu Mendulang Anak Berlari; (3) Relevansi Kumpulan Puisi Ibu Mendulang Anak Berari sebagai Materi Pembelajaran Puisi di SMA. Penelitian ini merupakan penelitian kualitatif. Teknik analisis yang digunakan dalam penelitian ini adalah teknik analisis interaktif dengan 3 komponen yaitu reduksi data, penyajian data dan simpulan data. Teknik validitas data yang digunakan adalah triangulasi dengan menggunakan triangulasi teori dan triangulasi sumber. Hasil Penelitian menunjukan bahwa (1) kumpulan puisi Ibu Mendulang Anak Berlari memiliki citra perempuan yang terdiri dari citra fisik, citra psiksi, dan citra sosial; (2) Terdapat gaya bahasa yang bervariatif dalam kumpulan puisi Ibu Mendulang Anak Berlari; (3) Terdapat relevansi kumpulan puisi Ibu Mendulang Anak Berlari sebagai materi pembelajaran puisi di SMA.
\end{abstract}

Kata Kunci: puisi, citra perempuan, gaya bahasa, materi ajar puisi, sekolah menengah atas

\section{WOMEN'S IMAGES AND LANGUAGE STYLES IN “IBU MENDULANG ANAK BERLARI” POETRY COLLECTION AS A LITERATURE LEARNING MATERIAL}

\begin{abstract}
This research has purpose to describe and explain; (1) The position of woman figure in collection of poetry Ibu Mendulang Anak Berlari by Cyntha Hariadi. (2) The language style of Poetry in Ibu Mendulang Anak Berlari. (3) The collection of poetry Ibu Mendulang Anak Berlari that can be used in a poetry learning material in senior high school. This research used the method of qualitative. Data analysis of this research used interaktif analysis within 3 components: data reducing, Data validity test is done by triangulating theory and triangulation of the data source. Based on the results of the study can be concluded: (1) on the poetry collection of ibu mendulang anak berlari has (a) Physical figure, (b) Physcological Figure, and (c) Social Figure; (2) Repetition is the most dominant style that used in the Ibu Mendulang Anak berlari poetry collection; (3) Ibu Mendulang Anak Berlari poetry collection can be used as a poetry learning material in senior high school, especially on KD 3.16 (Identifying the atmosphere, theme, and the meaning of poetry that has been read) and KD 3.17 (Analyze the elements of poetry).
\end{abstract}

Keywords: poetry, woman characteristic, language style, senior high school.

\section{PENDAHULUAN}

Pusi merupakan salah satu jenis karya sastra. Puisi berasal dari bahasa Yunani (Poeima) yang berarti membuat atau poeisis yang berarti pembuatan, dan dalam bahasa Inggris disebut Poetry atau poem (Aminudin, 2014: 134). Puisi sering dikaitkan dengan genre karya sastra lainnya seperti prosa, cerpen, novel, dan drama. Puisi telah diajarkan /dalam pembelajaran bahasa Indonesia di SMA.
Materi puisi diajarkan di semua jurusan baik kelas IPA, IPS, maupun Bahasa. Bursan (2014, 97) menyatakan bahwa materi menulis puisi terdapat pada pembelajaran yang diajarkan di kelas $\mathrm{X}$ yakni mengungkapkan pikiran dan perasaan melalui kegiatan menulis puisi. Widodo, Suwandi \& Tarjana (2013: 37) berpendapat bahwa dalam pembelajaran bahasa Indonesia ada beberapa aktivitas dalam standar isi yang berkaitan dengan

BASASTRA Jurnal Bahasa, Sastra, dan Pengajarannya 
puisi, mulai dari membaca puisi, menyimak puisi, mengapresiasi puisi, juga membuat puisi itu sendiri. Salah satu kegiatan mengapresiasi puisi adalah kegiatan mengambil dan menemukan arti tambahan yang dikandung dalam puisi tersebut, salah satunya adalah dengan menganalisis citra perempuan.

Citra merupakan ciri-ciri khusus dalam diri setiap individu, setiap individu tentunya memiliki keistimewaan yang membedakan dengan orang lain sehingga mampu dikenali. Citra mencerminkan bagaimana seseorang tersebut dipandang dan dilihat. Untuk mengungkapkan citra seseorang memerlukan kemampuan pengalaman indra manusia sehingga manusia dapat mengenali manusia lainnya. Pengalaman indra dapat melalui penglihatan, pendengaran dan perasa. Pengalaman-pengalaman indra tersebut kemudian diwujudkan melalui kata-kata untuk mengungkapkan citra seseorang. Sofia \& Sugihastuti (2009:24) menjelaskan bahwa citra adalah gambaran pengalaman indra yang diungkapkan lewat kata-kata, gambaran pengalaman berbagai pengalaman sensoris yang dibangkitkan lewat kata-kata.Perempuan memiliki karakteristik atau ciri khas yang membedakannya dengan laki-laki. Soetiyo (2013: 55) menjelaskan bahwa perempuan sebagai lawan jenis laki-laki digambarkan dengan citra-citra tertentu yang mengesankan inferioritas perempuan. Citra perempuan tidak semata-mata terbentuk langsung melainkan dari beberapa pengamatan yang terjadi dalam masyarakat. Beauvoir (2003: 459) memberikan penjelasan bahwa karakter atau identitas perempuan tidak melekat karena suatu keadaaan yang dilandasi oleh hormon atau kodratnya di dalam struktur otak kefeminisan melainkan hal yang dilandasi oleh situasi dan kondisi masyarakat.

Citra perempuan masuk ke dalam kajian ilmu feminisme karena membahas hal-hal yang berkaitan dengan perempuan. Feminisme membahas perempuan secara menyeluruh termasuk citra perempuan dan eksistensinya dalam masyarakat. Nuryati (2015: 165) menjelaskan feminisme adalah sebuah paham atau keyakinan bahwa perempuan benar-benar bagian dari alam manusia, bukan berasal dari gerakan yang menuntut kesetaraan dengan laki-laki. Citra perempuan berkaitan dengan ciri fisik, psikis, dan sosial yang dialami oleh perempuan. Wolfman (dalam Sugihatuti, 2000: 121) membagi citra perempuan dalam aspek sosial ke dalam dua peran, yaitu peran wanita dalam keluarga dan peran wanita dalam masyarakat

Perempuan dalam sastra telah menjadi suatu topik bahasan yang luas dan menarik. Dunia sastra mengenal kritik sastra feminis untuk menelaah perempuan baik karakteristik, peran ataupun citranya. Wiyatmi (2012:28) berpendapat bahwa kritik sastra feminis merupakan salah satu ragam dalam kajian sastra yang mendasarkan pada pemikiran feminisme yang menginginkan adanya keadilan dalam memandang eksistensi perempuan, baik sebagai penulis maupun karya-karya sastranya. Karya sastra pun telah menjelaskan bagaimana posisi, peran, kedudukan dan citra seorang perempuan dalam dunia sastra. Karya sastra sering menunjukan adanya dominasi laki-laki terhadap kaum perempuan dan menjelaskan bahwa perempuan adalah objek pemikiran dari laki-laki. Endraswara (2003:144) menjalaskan bahwa gejala kultural yang sering kali membedakan gender atas dasar kepentingan kelompok tertentu, dalam hal ini adalah laki-laki, dan karya sastra sering menjadikan wanita sebagai objek dibawah dominasi laki-laki. Sejalan dengan maraknya karya-karya sastra yang menjadikan perempuan sebagai objeknya. Bermunculan pula pengarang perempuan yang turut andil dan mengangkat perempuan sebagai tokoh utama dalam karya sastra dengan latar belakang yang mirip dengan kehidupan sehari-harinya. Djajanegara (2000:17-18) menjelaskan bahwa Peristiwa tersebut adalah hal baru dalam dunia sastra karena 
selama ini sastra lebih didominasi oleh pria, sehingga tolak ukur sastra adalah penulis pria.

Analisis puisi juga tak lepas dari analisis gaya bahasa karena pemilihan gaya bahasa memiliki pengaruh yang kuat dalam keberhasilan penulisan suatu puisi. Penyampaian pesan, ide, dan gagasan oleh pengarang dapat terlihat dari gaya bahasanya. Puisi merupakan realisasi ide dari pengarang sehingga puisi yang ditulis memiliki style tersendiri sesuai dengan pengarangnya. Setiap rangkaian kalimat, pemilihan kosa kata, diksi, dalam puisi dipengaruhi oleh penulisnya. Karakteristik penulis dapat tercermin dalam sebuah puisi yang ditulisnya karena tidak ada penulis yang sama. Hal ini sejalan dengan pendapat Pratikno (1984: 50) bahwa sifat, tabiat atau watak seseorang itu berbedabeda. Setiap penulis memiliki gaya penulisan yang berbeda-beda sehingga gaya bahasa dalam penulisan puisi menjadi sebuah unsur yang menarik untuk dikaji.

\section{METODE PENELITIAN}

Berdasarkan penelitian, metode dalam penelitian ini adalah kualitatif. Pada pelaksanaannya, penelitian ini tidak terikat tempat, waktu dan lembaga tertentu. Data yang dikumpulkan dan dikaji dalam penelitian ini berupa data kualitatif yaitu berupa kata-kata bukan berbentuk angkaangka. Sumber data yang digunakan dalam penelitian ini adalah Kumpulan Puisi berjudul Ibu Mendulang Anak Berlari karya Cyntha Hariadi yang diterbitkan oleh Gramedia Pustaka.

Penelitian ini mengambil sampel dengan cara purposive sampling, yaitu mengacu pada tujuan penelitian.Purposive sampling adalah pengambilan sampel yang diarahkan pada sumber data yang dipandang memiliki data penting dan juga berkaitan dengan permasalahan yang sedang diteliti (Sutopo, 2002:36). Teknik pengumpulan data yang digunakan adalah (1) Analisis isi untuk menjelaskan dan mengungkapkan gaya bahasa, serta citra perempuan dalam kumpulan puisi $I b u$ Mendulang Anak Berlari karya Cyntha
Hariadi; (2) Wawancara yang dilakukan dengan dosen sastra FKIP UNS, guru bahasa Indonesia dan murid SMA kelas XI. Wawancara bertujuan untuk mengetahui relevansi penelitian ini dalam dunia pendidikan khususnya pengajaran puisi; (3) Pengumpulan data yang berkaitan dengan kumpulan puisi $I b u$ Mendulang Anak Berlari.

Validitas data yang digunakan adalah triangulasi dengan menggunakan triangulasi teori dan triangulasi sumber. Triangulasi teori dilakukan dengan cara membandingkan teori satu dengan teori lainnya untuk mendapatkan teori yang paling benar dan terpercaya. Triangulasi sumber menggunakan hasil wawancara dengan informan untuk memvalidasi relevansi kumpulan puisi Ibu Mendulang Anak Berlari.

Teknik analisis yang digunakan dalam penelitian ini adalah teknik analisis interaktif dengan 3 komponen yaitu reduksi data, penyajian data dan simpulan data. (1) Reduksi data, peneliti mengambil data dan mengklarifikasi data berdasarkan permasalahan yang akan dikaji. Data dokumen yang diambil berupa puisi-puisi dalam kumpulan puisi Ibu Mendulang Anak Berlari yang mengungkapkan citra perempuan dan sesuai dengan materi ajar di SMA.

Data informan berupa transkrip wawancara dengan narasumber atau informan; (2).Penyajian data, pada tahap ini, peneliti menyusun data yang telah direduksi kemudian merakit data tersebut secara terperinci sehingga mudah dipahami. Susunan dari penyajian data ini mengacu pada rumusan masalah sehingga menjawab pertanyaan-pertanyaan yang ada; (3) Penyimpulan data, terjadi berdasarkan semua hal yang terdapat pada tahap-tahap sebelumnya. Setelah peneliti melakukan seleksi data, analisis data tentang citra perempuan dan gaya bahasa yang terdapat dalam kumpulan puisi Ibu Mendulang Anak Berlari dan relevansinya sebagai bahan ajar sastra di SMA yang 
kemudian dilakukan penarikan kesimpulan oleh peneliti.

\section{HASIL DAN PEMBAHASAN}

Penelitian ini bertujuan untuk menjawab pemasalahan mengenai citra perempuan, gaya bahasa serta relevansinya dalam pembelajaran puisi di SMA.

\section{Citra Perempuan}

Citra perempuan berkaitan dengan aspek fisik, psikis, dan sosial. Sugihastuti (2000: 112 - 113) menjelaskan bahwa citra diri seorang wanita merupakan situasi dan pandangan wanita yang berasal dari dalam dirinya, yang meliput aspek fisik dan aspek psikis. Secara fisik, tubuh wanita memiliki perbedaan dengan tubuh pria yang sifatnya alamiah. Nurhayati (2012: 16) menjelaskan suatu fakta biologis yang tidak dapat disangkal, perempuan dikodratkan untuk haid, hamil, melahirkan, dan menyusui. Tubuh Wanita dirancang sebagai makhluk yang dapat memunculkan individu baru dengan melahirkan anak, kemudian ciri biologis wanita memampukan seorang wanita untuk menyusui anaknya sendiri.

Abdullah (2006:3) berpendapat bahwa untuk memahami seorang perempuan diperlukan pemahaman mengenai jati diri atau identitas mereka berdasarkan nature (alam) \& budaya. Faktor alam berpengaruh terhadap aspek fisik, Faktor budaya berpengaruh terhadap psikis dan sosial perempuan. Berdasarkan hasil penelitian, diperoleh citra perempuan dalam kumpulan puisi Ibu Mendulang Anak Berlari meliputi: a) aspek fisik, b) aspek psikis, dan c) aspek sosial. Adapun paparannya dapat dilihat data sebagai berikut:

\section{Citra Perempuan dari Aspek Fisik}

(1)Aku akan menjadi ibu anak perempuanku

Sang bibit

Sang dara

Pada kalimat kedua (aku akan menjadi ibu anak perempuanku) menjelaskan citra fisis seorang perempuan karena yang bisa menjadi seorang ibu hanya seorang perempuan saja. Pada kalimat ketiga, (sang bibit) juga menjelaskan citra fisis seorang perempuan karena dari kalimat itu dapat menjelaskan asal seorang bayi yaitu dari rahim seorang perempuan

\section{(2)Kepala berkarak mendorong panggul}

Adapun hasil analisis data terdapat pada kalimat pertama. Melalui kalimat kepala berkarak mendorong panggul mencerminkan gambaran fisik seorang perempuan yang memiliki panggul. Melalui kalimat tersebut mencerminkan proses melahirkan yang dialami oleh perempuan.

(3)Ingat ayah mengambil dayung dan mendorong sampan, Ibu membuka kancing dan menetekimu

Adapun hasil analisis terdapat pada baris kedua melalui kalimat ibu membuka kancing dan menetekimu. Kalimat tersebut tidak bermakna vulgar melainkan menjelaskan bagaimana perhatiannya seorang ibu kepada anaknya. Membuka kancing dan menetekimu mencerminkan ciri fisis yang hanya terjadi pada diri seorang perempuan.

(4)Kutanggalkan satu-satu

Bawahan, atasan, beha, celana dalam

Tarik tirai bak mandi

Adapun uraian hasil analisis terdapat pada baris kedua melalui kalimat bawahan, atasan, beha, celana dalam. Kata beha menunjuk kepada citra fisis seorang perempuan karena beha yang ada dalam puisi tersebut merupakan baju dalam yang hanya digunakan oleh kaum perempuan saja

musuh

(5)Wajahnya terpupur mulus dan diwarnai indah

Siap menyilaukan teman atau

Data di atas mencerminkan ciri fisik seorang wanita. Wajahnya terpupur mulus berarti wanita tersebut menggunakan bedak untuk menambah kecantikan dirinya yang sudah mulus dan cantik. Sedangkan, kalimat diwarnai indah menjelaskan bahwa 
wajah wanita itu semakin cantik dengan pulasan warna di bibir dan wajahnya

(6)Ketika kau keluar dari tubuhku Ada makhluk lain yang masuk menggantikanmu

$\mathrm{Aku}$, yang tak pernah orang kenal apalagi kau

Kalimat dalam data di atas menjelaskan ciri fisik yang hanya dimiliki seorang wanita. Kalimat tersebut menjelaskan bahwa wanita dapat mengandung seorang anak dan melahirkannya setelah itu wanita dapat mengandung kembali degan proses yang sama secara berulang.

(7)Ibu memulas

Kini bibirmu seperti embun

Kalimat di atas mencerminkan ciri fisik wanita meski tidak digambarkan secara nyata. Pada baris kedua dengan kalimat kini bibirmu seperti embun juga menggambarkan kecantikan fisis wanita setelah ditambah dengan pelembab di bibirnya.

\section{Citra Perempuan dari Aspek Psikis}

(1)Sedang kubayangkan anak perempuanku tumbuh

Ketika ibuku menginjak duri di

Ia sinari kebun anaknya sendiri

Ia siangi

Paparan data di atas menjelaskan citra perempuan dari aspek psikis. Kata duri pada kalimat tersebut menggambarkan pengorbanan seorang ibu untuk anaknya Pada Ia sirami, Ia sinari, Ia siangi menjelaskan sifat seorang perempuan yang penyayang. Perempuan yang telah menjadi Ibu mengerahkan segenap usaha, tenaga, dan kemampuannya agar anaknya dapat memperoleh kehidupan yang lebih baik dan tumbuh dengan baik

(2)Ibu mengejan

Cengkeramannya membelah gunung

Anak meraung

Memadahkan entah kutuk atau pujian syukur
Paparan data di atas menjelaskan citra perempuan dari aspek psikis. Pada kalimat ibu mengejan menjelaskan susahnya proses melahirkan. Pada kalimat cengkeramannya membelah gunung menggambarkan sakitnya proses melahirkan. Meskipun sakit dan sulit, namun seorang ibu akan berjuang agar anak yang berada dalam rahimnya dapat melihat dunia luar. Kata mengejan menjelaskan sifat seorang Ibu yang pantang menyerah. Pilihan kata Cengeramannya menjelaskan kuatnya perempuan dalam menghadapi rasa sakit yang luar biasa ditengah proses melahirkan.

(3)Ingat ayah membelah pohon supaya kita punya rumah,

Ibu mengusap dadamu yang sesak

Data di atas menjelaskan citra perempuan dari aspek psikis. Data di atas menjelaskan perbedaan sifat karakteristik ibu dan ayah. Keduanya menaruh perhatian yang sama pada anaknya, namun perhatian ibu lebih terlihat nyata dan ibu merupakan sosok yang lebih dekat dengan anaknya. Pemilihan kata mengusap dadamu menggambarkan ibu adalah sosok yang lemah lembut dan penyayang.

(4)Setengah tertebus

Aku terjaga

Seberapa pun guruhnya air keran menelan ibu,ibu,ibu

Laranya yang sayup sanggup menegur kalbu

Kotor lagi kecil menjadi

Aku dosa karena mandi

Data di atas menjelaskan citra perempuan dari aspek psikis. Perempuan digambarkan sebagai sosok yang berhati lembut sehingga memiliki sifat yang tidak tegaan. Pada kalimat setengah tertebus menjelaskan perasaan bersalah seorang ibu, dalam kalimat tersebut seorang ibu tidak sepenuhnya merasa lega untuk mandi karena dia memikirkan anaknya yang ditinggalkan sesaat. Selanjutnya, pada kalimat kedua aku menggambarakan 
kondisi seorang ibu yang merasa gelisah memikirkan anaknya.

(5)Tasnya kecil anggun, berisi ideide dan pemikiran hebat

Sepatunya lancip dan tinggi, ia sejajar dengan para lelaki

Wanita itu menggerakan dunia

Pada kutipan data di atas menjelaskan sikap perempuan yang tangguh dan dapat sejajar dengan laki-laki. Pada kalimat Tasnya kecil anggun, berisi ide-ide dan pemikiran hebat menggambarkan perempuan sebagai pribadi yang tangguh dan luar biasa. Melalui kalimat berisi ide-ide dan pemikiran hebat menjelaskan bahwa meskipun seorang perempuan identik dengan sikap anggun, lemah lembut dan sensitif namun perempuan dapat memberikan kontribusi yang luar biasa pula di dalam pekerjaanya dan karena ketangguhannya wanita dapat menggerakan dunia.

(6)Tanganku yang memberimu makan

Kepalaku yang memberimu nasihat kehidupan

Pada kutipan data di atas menjelaskan sifat perempuan yang penyayang. Pada kalimat tanganku yang memberimu makan menggambarkan sikap perempuan yang penyayang. Pemilihan kata tanganku menggambarkan sikap lemah lembut seorang perempuan dalam memberi makan anaknya.

Selanjutnya, pada kalimat keempat kepalaku yang memberimu nasihat kehidupan menggambarkan sikap perempuan yang penyayang. Pemilihan kata nasehat menggambarkan sikap seorang ibu yang penyayang. Melalui nasehat, seorang ibu mencurahkan kasih sayangnya agar anaknya dapat hidup dan tumbuh dengan baik.

(7)Dingin di luar

Tak akan mampu menggigilkan ibu

Paparan data di atas menggambarkan citra perempuan dari aspek psikis. Melalui kalimat yang terdapat pada penggalan puisi di atas mencerminkan perempuan yang kuat. Hasil analisis data terdapat pada kalimat kedua. Melalui kalimat (Tak akan mampu menggigilkan ibu) menunjukan bahwa dalam situasi apapun seorang perempuan akan berusaha kuat dan tidak mengeluh.

\section{Citra Perempuan dari Aspek Sosial}

Citra perempuan dari asek sosial berupa citra perempuan sebagai orang tua, hubungan dalam kekerabatan, hubungan dalam keluarga, hubungan dengan orang lain, dan hubungan dalam lingkungan sosial.

(1)Aku anak perempuan ibuku

Aku akan menjadi ibu anak perempuanku

Uraian hasil analisis data terdapat pada kalimat pertama dan kalimat kedua. Kalimat pertama (aku anak perempuan ibuku) menjelaskan unsur kekerabatan antara ibu dan anak, pada kalimat tersebut pula dijelaskan citra sosial seorang perempuan sebagai anak. Kalimat kedua ( aku akan menjadi ibu anak perempuanku) menjelaskan citra sosial perempuan sebagai seorang ibu.

(2)Ibuku melahirkanku

Sebagai seorang anak

Anakku melahirkanku

Sebagai seorang ibu

Hasil analisis data terdapat pada kalimat pertama, kalimat kedua, kalimat ketiga, dan kalimat keempat. Pada kalimat pertama (ibuku melahirkanku) dan kalimat kedua ( sebagai seorang anak) menjelasakan hubungan kekerabatan serta citra sosial perempuan sebagai anak. Selanjutnya, pada kalimat ketiga (anakku melahirkanku) dan keempat ( sebagai seorang ibu) menjelaskan citra sosial perempuan yang telah berubah status sosialnya menjadi seorang ibu.

(3)Ingat ayah menggoloki daun pisang untuk alas tidur kita, Ibu mencuci rambut dan kakimu?

Ingat ayah mengumpulkan jerami supaya kita tidak kehujanan,

Ibu bernyanyi di telingamu? 
Melalui kata ayah dalam kalimatkalimat tersebut, menjelaskan bahwa citra sosial perempuan dalam kutipan di atas adalah sebagai seorang istri. Selanjutnya citra sosial perempuan sebagai ibu tergambar pada kalimat kedua (Ibu mencuci rambut dan kakimu), kalimat keempat ( ibu bernyanyi di telingamu), dan kalimat keenam (ibu memegangi tanganmu supaya kau tidak jatuh). Pada kalimat tersebut citra sosial perempuan sebagai ibu tergambar dari perilaku kasih sayang ibu terhadap anaknya. Pemilihan kata ibu juga menjelaskan bahwa perempuan yang ada dalam kutipan di atas merupakan seorang ibu.

(4) Mengalir masuk ke mulut mencari ibu, ibu, ibu

Tak berhenti sampai tersedak mukanya biru

Pemilihan kata dalam perulangan kata ibu,ibu, ibu menunjukan bahwa ada seorang perempuan yang dipanggil terus menerus dengan sebutan ibu. Kata Ibu sendiri telah mewakili citra sosial perempuan dalam masyarakat.

(5)Pakaiannya licin dan berwibawa, tak akan ada dia

Jatuh bertekuk lutut

Tasnya kecil anggun, berisi ideide dan pemikiran hebat

Sepatunya lancip dan tinggi, ia sejajar dengann para lelaki

Paparan data di atas menunjukan citra sosial perempuan. Melalui kalimat yang tersaji dalam kutipan data di atas dapat ditemukan gambaran hubungan perempuan dengan lingkungan sosialnya. Citra sosial perempuan yang tergambar pada kutipan data di atas adalah sebagai perempuan pekerja kantoran.

Pada kalimat pakaiannya licin dan berwibawa, tak akan ada dia menggambarkan bawa perempuan tersebut memang bekerja kantoran karena menggunakan pakaian yang telah dipersiapkan dengan baik. Kalimat tasnya kecil anggun, berisi ide-ide dan pemikiran hebat menjelaskan bahwa perempuan tersebut memiliki andil besar dalam dunia kerjanya. Kalimat sepatunya lancip dan tinggi, ia sejajar dengann para lelaki menunjukan sebagai seorang perempuan yang bekerja namun kedudukan dan posisinya sejajar dengan seorang pria.

(6)Sampai ibu mengecup

Barulah bibirmu merekah

Melambaikan tangan, kau siap ke sekolah

Citra sosial seorang perempuan tercermin melalui paparan data di atas. Perempuan sebagai seorang ibu nampak melalui kalimat-kalimat yang terdapat pada kutipan data di atas. Pemilihan kata ibu pada kalimat sampai ibu sudah menjelaskan citra sosial perempuan dalam masyarakat.

Gaya Bahasa dalam Kumpulan Puisi Ibu Mendulang Anak Berlari

Penggunaan Gaya Bahasa dalam Kumpulan Puisi Ibu Mendulang Anak Berlari

Abdurrahman (2016: 221) menjelaskan bahwa gaya bahasa dalam dunia sastra adalah gaya tulis menulis, yaitu penggunaan bahasa sebagai media ekspresi sastra. Hal tersebut sesuai dengan pendapat Kusnadi \& Sutejo (2010:46) yang menyatakan bahwa gaya bahasa digunakan pengarang untuk memberikan imaji dan mewujudkan estetika.

Berdasarkan hasil penelitian dalam 7 puisi yang dianalisis dalam kumpulan puisi Ibu Mendunga Anak Berlari ditemukan 15 gaya bahasa yang bervariatif. Gaya bahasa tersebut berupa paralelisme, retoris, anafora, asonansi, aliterasi, personifikasi, hiperbola, epitet, simile, paradoks, antitesis. alegori,aferesis, mesodiplosis, sinestesia.

Gaya bahasa yang terdapat dalam buku kumpulan puisi Ibu Mendulang Anak Berlari sangat bervariatif. Di antara gaya bahasa yang ditemukan, gaya bahasa penegasan retoris merupakan gaya bahasa yang paling sering digunakan oleh pengarang Cyntha Hariadi.Ditemukan 15 data penggunaan majas retoris. Berikut 
merupakan contoh kutipan gaya bahasa retoris.

(1) Ingat ayah memangkas ladang untuk rumah baru kita

Ibu menggendong sampai kau tertidur?

Data (1) di atas dapat dimasukan dalam gaya bahasa retoris. Pada data di atas terlontar sebuah pertanyaan uang diutarakan oleh sang ibu, namun sebetulnya pertanyaan tersebut tidak memerlukan jawaban karena merupakan dialog pribadi ibu dan dirinya.

Selanjutnya, terdapat gaya bahasa penegasan aferesis. Aferesis adalah gaya bahasa dengan menghilangkan beberapa konsonan sehingga menjadi sebuah singkatan. Ditemukan 3 data penggunaan gaya bahasa aferesis. Berikut merupakan contoh penggunaan gaya bahsa aferesis

(2) Tak berhenti sampai tersedak mukanya biru

Data (2) di atas dapat dimasukan dalam gaya bahasa aferesis karena terdapat penghilangan beberapa konsonan. Kata tidak disingkat menjadi kata tak sehingga lebih singkat.

Selanjutnya terdapat gaya bahasa pertentangan yaitu paradoks. Paradoks merupakan gaya bahasa bertentangan makna. Ditemukan 2 data penggunaan gaya bahasa paradoks. Berikut merupakan contoh gaya bahasa paradoks

(3) Menatap bulan Menatap matahari

Data (3) di atas dapat dimasukan dalam gaya bahasa paradoks karena terdapat pertentangan makna namun benar adanya. Kata bulan berarti malam sedangkan matahari merupakan kata bermakna siang.

Selanjutnya, terdapat gaya bahasa antitesis. antitesis merupakan gaya bahasa pertentangan yang merupakan lawan kata tersebut. Ditemukan 5 data penggunaan gaya bahasa anititesis. Berikut merupakan contoh penggunaan gaya bahasa antitesis

(4) Siap menyilaukan teman atau musuh
Data (4) di atas merupakan gaya bahasa antitesis. Teman dan musuh merupakan kata dengan arti yang berlawanan. Teman merupakan orang terdekat kita dan musuh adalh orang yang jauh dari kita dan cenderung tidak menyukai kita.

Selanjutnya terdapat gaya bahasa perulangan asonansi. Ditemukan 7 data penggunaan gaya bahsa asonasi dalam puisi yang dianalisis. Salah satu gaya bahasa asonansi yaitu:

(5) Sampai tanganya kelu Dan seluruh hatinya pilu

Data (5) di atas dapat dikategorikan dalam gaya bahasa asonansi, yakni gaya bahasa dengan perulangan bunyi pada akhir kalimat. Pada data di atas terdapat perulangan vocal "u" pada akhir kata. Kata kelu dan pilu menggunakan perulangan huruf u pada akhir katanya.

Selanjutnya terdapat penggunaan gaya bahasa perulangan yaitu anafora. Anafora merupakan gaya bahasa dengan perulangan kata atau kalimat. Ditemukan 7 data penggunaan gaya bahasa anafora. Berikut merupakan contoh penggunaan gaya bahasa anafora pada buku kumpulan puisi ibu mendulang anak berlari.

(6) Aku anak perempuan ibuku Aku akan menjadi ibu anak perempuanku

Data (6) di atas dikategorikan dalam majas anafora karena terdapat perulangan kata atau kalimat. Kata yang diulang dalam data tersebut adalah kata aku. Kata aku diulang sebanyak 2 kali.

Selanjutnya, terdapat gaya bahasa aliterasi, yaitu perulangan huruf konsonan minimal sebanyak dua kali dalam satu kalimat. Ditemukan 2 data penggunaan gaya bahasa aliterasi. Berikut merupakan contoh penggunaan gaya bahasa aliterasi

(7) Sebagai Seorang Anak

Data (7) di atas dapat dimasukan dalam majas aliterasi karena terdapat perulangan konsonan yang samma pada awal kalimat. Perulangan konsonan terjadi sebanyak dua kali. Kata sebagai dan kata 
seorang menggunakan konsonan se diawal kata.

Selanjutnya terdapat gaya bahasa mesodiplosis, yaitu perulangan kata pada tengah kalimat. Terdapat 2 data penggunaan majas mesodiplosis.

(8) Pada hari aku mati

Tolong bantu aku mengingat ini

Data (8) di atas dapat dimasukan dalam majas mesodiplosis karena terdapat perulangan kata di tengah kalimat. Kata aku diulang sebanyak dua kali pada tengah kalimat.

Selanjutnya terdapat gaya bahasa perbandingan, yaitu personifikasi. Personifikasi adalah majas yang melekatkan sifat manusia pada benda mati sehingga seolah-olah hidup. Ditemukan 3 data penggunaan gaya bahasa personifikasi. Berikut merupakan contoh penggunaan gaya bahasa personifikasi.

(9) Seberapa keras guruhnya air keran menelan ibu,ibu,ibu

Data (9) di atas dikategorikan dalam majas personifikasi karena mengibaratkan benda mati memiliki kehidupan layaknya seorang manusia. Air keran diibaratkan memiliki nyawa dan mampu menelan seseorang. Padahal maksud puisi di atas adalah suara air keran mampu menyamarkan teriakan seorang anak memanggil ibunya.

Gaya bahasa perbandingan selanjutnya adalah hiperbola, yaitu gaya bahasa dengan melebih lebihkan suatu makna. Ditemukan 2 data penggunaan gaya bahasa hiperbola. Berikut merupakan contohnya

(10) Wanita itu menggerakan dunia

Data (10) di atas dapat dimasukan dalam gaya bahasa hiperbola karena melebih lebihkan sesuatu sehingga terkesan bombastis. Seorang wanita diibaratkan memiliki kekuatan yang luar biasa sehingga mampu menggerakan dunia.

Selanjutnya, terdapat gaya bahasa perbandingan epitet. Epitet mengacu pada sifat khusus seseorang. Ditemukan satu data epitet yaitu:
(11) Sepatunya lancip dan tinggi Ia sejajar dengan kaum pria

Data (11) di atas dapat dikategorikan dalam gaya bahasa epitet karena terdapat kalimat yang mengungkapkan acuan sifat seseorang yang tegas. Sepatu lancip dan tinggi mengibaratkan bahwa seseorang tersebut tegas dan kedudukannya dapat sejajar dengan pria.

Selanjutnya terdapat gaya bahasa perbandingan simile. Simile merupakan gaya bahasa perbandingan dengan menggunakan kata pembanding. Ditemukan 5 data penggunaan gaya bahasa simile. Berikut merupakan contoh peenggunaan gaya bahasa simile.

(12) Tasnya besar seperti mau perang

Data (12) di atas dapat dikategorikan dalam gaya bahasa simile karena menggunakan kata pembanding. Kata pembanding yang digunakan adalah kata seperti.

Selanjutnya, terdapat gaya bahasa perbandingan alegori. Alegori merupakan majas perbandingan dengan alam sekitar. Ditemukan 1 data penggunaan majas alegori yaitu:

(13) Bagai sungai deras air mata dan ingusnya

Majas alegori merupakan majas perbandingan dengan alam. Data (13) di atas dapat dimasukan dalam majas alegori karena terdapat perbandingan sungai dengan air mata dan ingus yang sama-sama deras.

Selanjutnya, terdapat gaya bahasa sinestesia. Sinestesia merupakan gaya bahasa dengan penggunaan panca indra manusia. Berikut merupakan data penggunaan gaya bahasa sinestesia:

(14) Dingin di luar

Data (14) di atas dapat dimasukan dalam gaya bahasa sinestesia karena terdapat penggunaan indra manusia untuk merasakan dinginya udara luar. Indra manusia yang digunakan adalah indra perasa sehingga mampu merasakan udara dingin sekitar. 
Selanjutnya, terdapat gaya bahasa penegasan paralelisme. Paralelisme merupakan gaya bahasa untuk menegaskan suatu makna dengan kesejajaran suatu kata atau frasa. Ditemukan 5 data penggunaan gaya bahasa paralelisme. Berikut merupakan contoh penggunaan gaya bahasa paralelisme

(15) Megap-megap

Data (15) dapat dikategorikan dalam majas paralelisme karena terdapat suatu kesejajaran makna dalam sebuah kata kata. Kata megap diulang sehingga membentuk kalimat megap-megap yang berarti sulit bernafas.

Selanjutnya, terdapat gaya bahasa penegasan retoris. Gaya bahasa retoris adalah gaya bahasa yang tidak memerlukan sebuah jawaban atas pertanyaan yang disampaikan. Terdapat 15 data penggunaan gaya bahasa retoris.

Tabel 1 Distribusi Penggunaan Gaya Bahasa

\begin{tabular}{clcc}
\hline No & Gaya Bahasa & Penggunaan & $\%$ \\
\hline 1 & Retoris & 15 & $24 \%$ \\
\hline 2 & Aferesis & 3 & $4,8 \%$ \\
\hline 3 & Paradoks & 3 & $4,8 \%$ \\
\hline 4 & Antitesis & 3 & $4,8 \%$ \\
\hline 5 & Asonansi & 3 & $4,8 \%$ \\
\hline 6 & Aliterasi & 3 & $4,8 \%$ \\
\hline 7 & Anafora & 7 & $11,2 \%$ \\
\hline 8 & Mesodiplosis & 2 & $3,2 \%$ \\
\hline 9 & Personifikasi & 2 & $3,2 \%$ \\
\hline 10 & Hiperbola & 2 & $3,2 \%$ \\
\hline 11 & Epitet & 7 & $11,2 \%$ \\
\hline 12 & Simile & 5 & $8 \%$ \\
\hline 13 & Alegori & 1 & $2 \%$ \\
\hline 14 & Sinestesia & 1 & $2 \%$ \\
\hline 15 & Paralelisme & 5 & $8 \%$ \\
\hline & & 62 & $100 \%$ \\
\hline
\end{tabular}

Berdasarkan tabel di atas, gaya bahasa yang didapat sejumlah 62 data. Dari keseluruhan data, gaya bahasa retoris merupakan gaya bahasa yang paling dominan dengan presentase $24 \%$.

\section{Relevansi Buku Kumpulan Puisi Ibu Mendulang Anak Berlari Karya Cyntha Hariadi sebagai Materi Ajar Puisi di SMA}

Berdasarkan hasil analisis dari 7 puisi yang dipilih dalam kumpulan puisi Ibu Mendulang Anak Berlari. Buku kumpulan puisi Ibu Mendulang Anak Berlari dinilai memenuhi standar kelayakan dengan hasil layak. Materi dan isi yang disajikan tidak menyinggung pihak-pihak tertentu, tidak terdapat unsur SARA, dan tidak menggiring opini publik untuk mendukung suatu pihak manapun. Selain itu, buku tersebut tidak terdapat suatu unsur yang bertentangan dengan uandang-undang dan ideologi negara.

Penyajian buku kumpulan puisi $\mathrm{Ibu}$ Mendulang Anak Berlari sistematis sehingga mudah dipahami, tata letak puisi rapi dan terurut mulai dari proses kelahiran manusia hingga kematian sehingga menumbuhkan motivasi siswa untuk membaca lebih mendalam. Selanjutnya, bahasa yang digunakan dalam buku tersebut ringan, mudah dipahami, dan tidak berbelit-belit. Buku tersebut juga memuat nilai-nilai kreativitas dalam bahasa yang digunakanya, memuat citra perempuan, dan memuat gaya bahasa yang beragam. Buku kumpulan puisi Ibu Mendulang Anak Berlari dapat digunakan dalam KD 3.16 dan 3.17.

\section{SIMPULAN}

Berdasarkan hasil analisis dan pembahasan puisi-puisi dalam kumpulan puisi ibu mendulang anak berlari, dapat ditarik kesimpulan bahwa terdapat citra perempuan dari aspek fisik, psikis dan sosial. Keseluruhan puisi yang dianalisis memenuhi ketiga aspek tersebut. Keseluruhan puisi menggambarkan bagaimana kehidupan seorang ibu sehingga aspek sosial yang dominan adalah perempuan sebagai seorang ibu. Sedangkan dari aspek fisik, terdapat pengungkapan ciri fisik perempuan secara tersirat.

Pengarang memanfaatkan gaya bahasa yang beragam dalam setiap puisi yang dianalisisnya. Terdapat 62 gaya bahasa dari 7 puisi yang dianalis dalam buku kumpulan puisi Ibu Mendulang Anak Berlari. Gaya bahasa yang dominan adalah gaya bahasa retoris dengan presentase 24\%. Namun, untuk jumlah pemakaian 
jenis gaya bahasa, perulangan merupakan gaya bahsa yang dominan.

Puisi dapat dijadikan sebagai materi ajar puisi di SMA karena tidak terdapat unsur sara ataupun melecehkan pihak tertentu. Selain itu gaya bahasa yang digunakan beragam seingga dapat dijadikan pembelajaran di sekoalah.

Penelitian ini diharapkan dapat menjadi bahan masukan yang bermanfaat

\section{REFERENSI}

Abdullah, I. (2006). Seks, Gender dan Reproduksi kekuasaan: Yogyakarta: Terawang Press.

Abdurrahman, I.B (2016). Stylistics Analysis Of Complexity In William Faulkners "A Rose For Family". 7(4), 221-222.

Aminudin. (2014). Pengantar Apresiasi Sastra. Bandung: Sinar Baru Algensindo.

Bursan, I. Z. (2014). Peningkatan Keterampilan Menulis Puisi Siswa Kelas X SMA Negeri 3 Bulukumba Kabupaten Bulukumba Melalui Strategi Pembelajaran Sugestopedia. Jurnal Pena. 1(1). 96-108.

Beauvoir. (2003). The Second sex, book two: Women Life Today. New York: Vintage.

Djajanegara, S. (2000). Kritik Sastra Feminis: Sebuah Pengantar. Jakarta: Gramedia.

Endraswara, S. (2003). Metodologi Penelitian Sastra. Yogyakarta: Pustaka Widya Tama.

Kusnadi \& Sutejo (2010). Apresiasi Prosa. P2MP: Spectrum Ponorogo. Yogyakarta: Pustaka Felicia. bagi pihak-pihak tertentu. Khususnya bagi guru Bahasa Indonesia dan siswa kelas $\mathrm{X}$ SMA. Guru dapat mengambil nilai positif dan dapat menjadikan puisi dalm buku kumpulsn puisi Ibu Mendulang Anak Berlari sebagai referensi materi ajar karena sesuai dengan KD 3.16 dan 3.17 yaitu mempelajari makna puisi.

Nuryati. (2015). Feminisme dalam Kepemimpinan. Jurnal Istinbat. 16(4). 161-179.

Pratikto, R. (1984). Kreatif Menulis Feature. Jakarta: Balai Pustaka

Soetiyo. (2013). Citra Perempuan dalam Novel Perawan Remaja dalam cengkraman Militer Karya Pramoedya Ananta Toer. Jurnal Ilmiah STKIP. PGRI Ngawi. 9(1). 37-52.

Sofia, A, \& Sugihastuti. (2003). Feminisme dan Sastra: Menguak Citra Perempuan " Layar Terkembang”. Bandung: Katarsis.

Sugihastuti. (2000). Kritik Sastra Feminis, Teori dan Aplikasinya. Yogyakarta: Pustaka Pelajar.

Sutopo.(2002). Metode Penelitian Kualitatif: Dasar Teori dan Penerapannya dalam Penelitian Sastra. Surakarta: Sebelas Maret University Press.

Wiyatmi. (2012). Kritik Sastra Feminis Teori dan Aplikasinya dalam Sastra Indonesia. Yogyakarta: Penerbit Ombak. 